\title{
Reflections on the Innovation of Legal Construction in Colleges and Universities of Jilin Province
}

\author{
Li Henan ${ }^{1, a}$, Lu Yu ${ }^{2, b}$ \\ ${ }^{1}$ School of Liberal Education, Jincheng College of Sichuan University, Chengdu, Sichuan, China \\ 611731 \\ ${ }^{2}$ Department of law, College of Humanities and Sciences of Northeast Normal University, \\ Changchun, Jilin, China 130117 \\ a782361573@qq.com, byuluaiyue@163.com
}

Key words: Jilin province university; legal construction; innovation

\begin{abstract}
Jilin Provincehas made a lot of achievements in all aspects about the implementation of the rule of law for many years. But the school needsinnovation in the network system, the system, the supervision system and other aspects of system, so as to straighten out the internal and external relations, to explore the path of running schools according to law, establish and improve the modern university system.
\end{abstract}

\section{The status quo of the rule of law in Jilin province}

Jilin Province from the regional point of view, Jilin Province, local education authorities have further increased the construction of the rule of law in education, so education laws and regulations construction have made many new achievements. They also actively put forward a number of local laws and regulations to promote the construction of the rule of law in colleges and universities, which has laid a solid foundation for the rule of law construction in Jilin province.

The basic system of the construction of the rule of law in Jilin Province has been established, and the system of democratic supervision and democratic decision-making has been established. In the course of the development of the rule of law in recent years, the role of the rule of law construction has been gradually highlighted and the system has been perfected.

Jilin Province, through the importance and strengthening of public affairs system, democratic decision-making system and faculty congress system, can promote democratic construction, strengthen democratic management, improve democratic supervision, and effectively protect the staff of the school affairs management of democratic participation and democratic supervision, which can expand the faculty democratic decision-making, democratic management and democratic 
supervision of the effective channels.

\section{The problems faced by the rule of law in Jilin province}

In the legal system, it belongs to the part of China's educational legal system, and the laws and regulations in China's education field belong to the relationship between the lower law and the upper law. The colleges and universities in our province do not fully take into account the state laws and administrative regulations of the relevant provisions, resulting in the school's rules and regulations and our current laws conflict with the phenomenon of frequent occurrence, cutting their own to create a lot of power.

From the micro perspective, the rules and regulations of colleges and universities are too abstract and lack of operability. The feasibility of the rules and regulations of colleges and universities is not strong, and the actual situation of colleges and universities in the development process is not effectively considered, which leads to the inability of law and management to be effectively integrated. From a macro perspective, the rules of the university should cover multiple social relations, because it is not independent of the existence of society, it is a part of society, it involves a lot of social relations, such as colleges and universities, universities and teachers, colleges, students, parents and so on. However, the current rules and regulations of colleges and universities clearly focus on the obligations, light rights, centralized management and other phenomena, and did not take into account the existence of various relationships, and there is no real right to reflect the rules. Colleges and universities to achieve the rule of law, must rely on the law to manage the campus, relying on the law to develop a reasonable situation in line with the rules and regulations, otherwise it will hinder the process of building the rule of law in colleges and universities.

Democracy and freedom is the prerequisite for the rule of law, which cannot be separated from democracy. But at present in the university of Jilin Province, the traditional thinking of people deeply rooted in the management system, administrative management to penetrate into all aspects of school management. At present, the university in Jilin Province is divided into two parts, one is the public institutions, the other is the private institutions, for the public institutions, the executive-led academic, become the administrative vassal, academic freedom and democracy cannot play, so that the school simply cannot let hands and feet engage in academic, engage in research, the university was seriously administrative. In the private colleges and universities, the chairman is the decision-making person, so decision-making has great limitations, resulting in a lot of arbitrary work, without a valid argument to blindly carry out, which runs counter to the rigor of the law. Over time, it will seriously affect the quality of students, and ultimately endanger the university's own survival. 
In the popularization and education of the school, the school is more concerned with the provisions of the school rules and regulations, through the meeting to convey the rule of law documents, turned on the form of learning experience, or to carry out legal knowledge Q \& A. Colleges and universities in order to achieve "law", vigorously strengthen the rules and regulations of the school rules and regulations. Even the rules and regulations of some colleges and universities are only temporary set up rules and regulations, they are not legal professionals, these regulations are often contrary to the law itself. For example, some colleges and universities in order to prevent violations of discipline, provision is no legal basis. This legal consciousness is weak, so that the spirit of the rule of law is completely lost, let alone the spread of the rule of law faith, over time, the rule of law construction is only a slogan and with a strong "administrative" color management.

\section{Jilin Province, specific methods of innovation in the construction of the rule of law}

First of all, the monitoring of university network speech must be strengthened. Now, as for many "hot spots" problem, some students are keen to express the negative meaning of the event, tend to spread some unexpected negative information, so to strengthen the university network public opinion monitoring is to promote the internal structure of the campus adjustment, and is an important way to promote the university to legalization, standardization.

Second, the network in the dissemination of mainstream thinking in the role of tools must be strengthened. The key to strengthen the role of the law in the network in disseminating the mainstream thinking is to always adhere to the important thinking of Marxism-Leninism, Mao Zedong Thought, Deng Xiaoping Theory and the "Three Represents", thoroughly implement the scientific concept of development, always adhere to the majority of faculty and students of the dominant position, specifically with the rules and regulations to regulate staff, students thinking and school management, so that there are laws to follow, there must be legal.

First of all, the procedures of legislationmust be improved. To improve the procedural legislation is an important part of the construction of the program system. In the process of standardizing the process of legislation should be specific, clear, the process should be standardized, refined, not too principle, so that operational loopholes, buried hidden risks, according to the principle of the maximum protection of the legitimate rights and interests of students.

Second, the rules and regulations of colleges and universities should be legalized. In the development of the constitution before the relevant professional knowledge of the staff to participate in the school rules and colleges and every member of the university are closely related to the school leadership cannot simply as the main body, to form a student representatives, teacher representatives, alumni and legal experts for the main body of the development team. So that the 
development of the rules and regulations of the legal system.

And finally improve the system of the violation of the rights of students. The improvement of the students'procedural system is not perfect, and the reasonable student complaint system will guarantee the students' right of defense and enable the students to talk with the school on the equal platform.

First, the relevant mechanismshould be established, which can actively and steadily push forward school affairs. Public affairs as an important measure can promote the construction of democratic politics and strengthen the internal management of schools. School open approach can develop specific rules and implementation details, and in the specific implementation process gradually explore the experience to make it standardized. The school's major issues such as some major decision-making, the construction of important facilities in the school, financial information, staff salaries and benefits, rewards and punishments system, enrollment information, leading cadres and other issues related to clean government construction as an important part of the school, to improve the public school procedures, in strict accordance with the procedures for public.

Second, the intensity of the rule of law propaganda should be increased, to strengthen the evaluation of the rule of law in colleges and universities to check. The school according to the law of the school should conduct guidance and inspection, so that school education along the legal system of healthy development, can achieve the true sense of the rule of law.

And finally, a self-evaluation mechanism that conforms to the actual school-based rule of law should beestablished. According to the law of the school will experience the "work of the implementation of a review of the effectiveness of a work to improve the work of repeated" spiral rise process. According to the requirements of education laws and regulations, colleges and universities should develop university charter, improve the internal governance structure of colleges and universities, vigorously promote the work of the school by law, also establish and improve the internal evaluation mechanism of the work according to the law. According to the "all to promote the implementation of the law according to the implementation of the principle" requirements, regularly according to the law of the school as the annual work of the special content, submitted to the education department for supervision.

First of all, the relationship between universities and governmentmust be correctly positioned. To rationalize the relationship between the government and the university, not only in the government to change its functions, but also in every aspect of education administration to improve the management of legal forms and methods of regulation. Foreign education developed countries, has long been completed by the organizers to the managers of the transition, with the legal, economic, planning, assessment, supervision, information services and the necessary administrative means of 
higher education organizations and leadership, overall planning and macro management higher education work, and its methods, mechanisms and means is undoubtedly worthy of our reference. Followed by the establishment of specialized institutions in the legal institutions. A specialized legal institution in a university may act as a school legal adviser to handle school affairs, including litigation legal affairs and non-litigation legal matters such as notarization, trademark registration and patent applications, and to safeguard the lawful rights and interests of the school. Second, it can be used as a school system audit institutions, school management decision-making to provide a legal basis to ensure the legitimacy of decision-making, which will make school management decisions and internal rules and regulations more reasonable and legitimate. Once again, it can be used as a school law enforcement supervision agencies, on the one hand the difficulties of law enforcement in colleges and universities can provide advice, timely correction of law enforcement in the process of illegal and irregularities, on the other hand, according to the law the violation of local governments, institutions or higher authorities on the legitimate rights and interests of colleges and universitiescan be resisted. It can serve as a legal advisory body for teachers and students to provide legal advice and legal services, and effectively safeguard the legitimate rights and interests of school teachers and students. In addition, it can also be used as legal propaganda agencies to fulfill the functions of legal mission, through a variety of forms in teachers and students to carry out thorough law education.

\section{References}

1.Duan Zhenwen: Study on the Risks of Local Government Financing Platform Loans and Its Influencing Factors.2014, Journal of China Agricultural University.p114.

2.Chen Zhiyong, Chen Sixia: Institutional environment, local government investment impulse and financial budget soft constraints. Economic Research Journal, 2014(03):p.76-87.

3.Zhu Jun, Nie Qun: Research on China 's Financial Sustainability under the Condition of Intertemporal Budget Constraints. Journal of Zhongnan University of Economics and Law, 2014(05): p.51-58+159.

4.Wang Yaling, Wang Lijie: Signal Game in the Formation of Local Debt: Real Estate Price Also on the Influence of New Budget Law. Economic Perspectives, 2015(04):p59-68.

5.Ba Shusong: To Resolve the Debt Risk Needs "Combined Boxing". Review of Economic Research, 2014(36):p12-13.

6.Lin Yifu: The Real Estate and Local Government Debt Risk Needs Utmost Attention. Guangdong Economy, 2014(09):p8. 